\title{
Properties of a Prolactin Receptor from the Rabbit Mammary Gland
}

\author{
By ROBERT P. C. SHIU* and HENRY G. FRIESEN* \\ Department of Experimental Medicine and the McGill University Clinic, Montreal, Que., Canada
}

(Received 14 November 1973)

\begin{abstract}
Receptors for human, simian, ovine, bovine and murine prolactin, human growth hormone and human placental lactogen have been identified in plasma-membrane-containing subcellular particles isolated from rabbit mammary glands. The association and dissociation of ${ }^{125} \mathrm{I}$-labelled prolactin are time- and temperature-dependent processes, both being maximal at $37^{\circ} \mathrm{C} .{ }^{125} \mathrm{I}$-labelled prolactin prepared by the enzymic iodination procedure with lactoperoxidase binds better to receptors than does the preparation obtained by using chloramine- $\mathrm{T}$ as the oxidizing agent. The binding of ${ }^{125} \mathrm{I}$-labelled prolactin to receptors is strongly influenced by $\mathrm{pH}$ and ionic composition but not by many low-molecular-weight compounds tested, e.g. steroids, nucleotides and several drugs. Receptor activity is sensitive to trypsin and phospholipase $\mathrm{C}$ digestion, suggesting that protein and phospholipid moieties are essential for the binding of ${ }^{125}$ I-labelled prolactin. The binding of ${ }^{125} \mathrm{I}$ labelled prolactin to receptors is a saturable and reversible process. Scatchard and Lineweaver-Burk analyses suggest that ${ }^{125} \mathrm{I}$-labelled prolactin has a high affinity for its receptor. Binding of ${ }^{125} \mathrm{I}$-labelled prolactin to receptors does not result in the destruction of the hormone. Considerable prolactin-binding activity is also observed in subcellular fractions isolated from the adrenal gland, liver, ovary and kidney of the pregnant rabbit, a finding that is consistent with other reported actions of prolactin in these organs.
\end{abstract}

It is generally accepted that in mammals one of the principal target tissues for prolactin is the mammary gland. The direct effects and the mechanism of action of prolactin on mammary growth, differentiation and function have been examined extensively (Cowie \& Tindal, 1971). Turkington (1970) reported that prolactin covalently linked to Sepharose beads is biologically active on mouse mammary epithelial cells and he suggested that prolactin initiates its effect by an action on the cell membrane because it is presumed that the Sepharose-prolactin complexes do not enter the cells. Falconer (1972) and Birkinshaw \& Falconer (1972) have demonstrated that ${ }^{125}$ I-labelled ovine prolactin binds to rabbit mammary tissue in vitro and in vivo and their radioautographic studies showed that the ${ }^{125} \mathrm{I}$-labelled prolactin that is associated with the epithelial cells is localized on the surface of the cell adjacent to capillaries. Further, Turkington (1971) has reported that ${ }^{125}$ I-labelled prolactin binds to membrane preparations isolated from cultured mammary tissue obtained from midpregnant mice. However, the limited amount of tissue that can be obtained from this source precludes extensive studies on the properties of the prolactinbinding sites, operationally termed 'receptors'. In a preliminary communication we have reported on the identification of a prolactin receptor in a particular preparation isolated from the mammary glands of

\footnotetext{
* Present address: Department of Physiology, University of Manitoba, 770 Bannatyne Avenue, Winnipeg, Manitoba R3E 0W3, Canada.
}

pregnant rabbits (Shiu et al., 1973). The present study gives detailed data on the interaction between prolactin and its receptors, which are found in a membrane-containing fraction obtained from mammary tissue homogenate. These studies form a rational basis for the further characterization, isolation and purification of the prolactin-binding structures and the development of a competitive-binding radioreceptor assay for prolactin and lactogenic hormones. The assay has been reported elsewhere (Shiu et al., 1973).

\section{Materials and Methods}

\section{Materials}

Human prolactin was purified in this laboratory (Hwang et al., 1972). Purified human growth hormone and ovine prolactin were obtained from the National Institute of Arthritis and Metabolic Diseases, National Institutes of Health, Bethesda, Md., U.S.A. Thyrotrophin-releasing hormone was obtained from Abbott, Chicago, Ill., U.S.A. All steroid hormones were purchased from Sigma, St. Louis, Mo., U.S.A. Bovine serum albumin (fraction V) was obtained from Miles Laboratory, Kankakee, Ill., U.S.A. Lactoperoxidase was from Calbiochem, La Jolla, Calif., U.S.A. Phospholipase C (Clostridium perfringens) and ribonuclease $\mathrm{A}$ (bovine pancreas) were purchased from Worthington, Freehold, N.J., U.S.A. Trypsin (bovine pancreas), soya-bean trypsin inhibitor, deoxyribonuclease I (bovine pancreas) and 
neuraminidase ( $\mathrm{Cl}$. perfringens) were obtained from Sigma. All nucleotides were from Sigma. 2-Bromo- $\alpha-$ ergocryptine (CB 154), a product of Sandoz Ltd., Basle, Switzerland, was generously provided by Dr. E. del Pozo (Sandoz). $\mathbf{N a}^{125} \mathrm{I}$ (carrier-free) was purchased from New England Nuclear, Boston, Mass., U.S.A. $\mathrm{H}_{2} \mathrm{O}_{2}(30 \%$,v/v, solution) was obtained from Fisher Scientific, Fair Lawn, N.J., U.S.A. All other reagents and chemicals were reagent grade. Sephadex was purchased from Pharmacia, Uppsala, Sweden. New Zealand White rabbits were supplied by Fauna Breeding Laboratory, Montreal, Que., Canada.

\section{Preparation of prolactin-binding subcellular particles}

Initially, mid-pregnant rabbits (days 15-19) were injected intramuscularly with $10 \mathrm{mg}$ of human placental lactogen and $5 \mathrm{mg}$ of cortisone daily for 4 days to give maximal stimulation of their mammary glands (Friesen, 1966), and mammary glands dissected from these hormone-primed rabbits were used as the starting materials for the preparation of receptor particles. However, subsequently it became apparent that mammary tissues obtained from pregnant rabbits 1 or 2 days before delivery or from rabbits in early lactation possess similar prolactin-binding characteristics. Therefore some experiments were carried out by using membrane particles isolated from mammary glands obtained from this group of rabbits. Further procedures for isolation of crude membrane particles and purified plasma membranes that bind ${ }^{125} \mathrm{I}-$ labelled prolactin have been reported (Shiu et al., 1973). It is worthwhile, however, to mention that the homogenization of the mammary tissue can be carried out in a Polytron homogenizer (Brinkmann) type PT 10 (1 min at full speed).

\section{Enzyme assay}

$5^{\prime}$-Nucleotidase activity was assayed as described by Widnell \& Unkeless (1968), except that trichloroacetic acid was used to precipitate particulate protein and the supernatant was assayed for $P_{1}$. Moreover, $10 \mu \mathrm{M}$-sodium-potassium tartrate was used in the assay incubation to inhibit acid phosphatase activity (El-Aaser \& Reid, 1965). One unit of enzyme activity is defined as the activity that liberates $1 \mu \mathrm{mol}$ of $P_{1}$ from $\mathrm{AMP} / \mathrm{min}$.

\section{Preparation of labelled hormone}

Human and ovine prolactin and human growth hormone were iodinated at room temperature by using a procedure similar to that of Thorell \& Johansson (1971) involving lactoperoxidase and $\mathrm{H}_{2} \mathrm{O}_{2}$, except that the reaction was allowed to proceed for $1 \mathrm{~min}$. Iodinated hormones were also prepared by the method of Hunter \& Greenwood (1962) by using chloramine-T as the oxidizing agent. To remove unreacted $\mathrm{I}^{-}$and damaged hormone, the mixture was fractionated on a column $(1.5 \mathrm{~cm} \times 50 \mathrm{~cm})$ of Sephadex G-100 previously equilibrated with Tris- $\mathrm{HCl}$ buffer (0.025 $\mathrm{M}$; pH7.6). Generally three radioactive peaks were observed. The radioactive material that was eluted in the void volume represented damaged and aggregated hormone. This material was discarded because it did not bind to receptors when subsequently tested. The radioactive material that was eluted from the column at a position where the native hormone appears was used for all binding studies. This material generally shows superior binding to receptors (see the Results section) and normally $70-90 \%$ can be precipitated by excess of antibodies. The third radioactive peak represented free $\mathrm{I}^{-}$.

The specific radioactivity of the labelled hormone was determined as follows. After the reaction had been stopped, $5 \mu \mathrm{l}$ of the iodination mixture was taken out and diluted with Tris- $\mathrm{HCl}$ buffer, $\mathrm{pH} 7.6$, containing $0.1 \%(\mathrm{w} / \mathrm{v})$ bovine serum albumin such that $1 \mathrm{ml}$ of the diluted mixture gives about 50000 c.p.m. Duplicate samples were used as a routine. Then $2 \mathrm{ml}$ of cold $10 \%(\mathrm{w} / \mathrm{v})$ trichloroacetic acid was added to give a final concentration of about $7 \%$ trichloroacetic acid. The tubes were mixed and then left at $4^{\circ} \mathrm{C}$ for $1 \mathrm{~h}$ before centrifugation at $750 \mathrm{~g}$ for $10 \mathrm{~min}$. The radioactivity that was precipitated by trichloroacetic acid was assumed to be associated with the protein hormone and the trichloroacetic acid-soluble radioactivity was assumed to represent free $\mathrm{I}^{-}$. The percentage of radioactivity incorporated into the hormone was thus obtained. By knowing the amount of hormone and $\mathrm{Na}^{125} \mathrm{I}$ used, as well as the counting efficiency, the specific radioactivity of the iodinated hormone could be calculated. The specific radioactivity of ${ }^{125} \mathrm{I}$-labelled prolactin obtained by using the lactoperoxidase method was generally between 60 and $120 \mu \mathrm{Ci} / \mu \mathrm{g}$, and that obtained by using chloramine-T was about $100-150 \mu \mathrm{Ci} / \mu \mathrm{g}$.

\section{Procedure for testing prolactin-binding activity}

The procedure was similar to that described previously (Shiu et al., 1973). The crude membrane fraction was used in all the studies unless otherwise noted. It was subsequently found, however, that the binding of ${ }^{125} \mathrm{I}$-labelled prolactin to receptors reaches equilibrium after $5 \mathrm{~h}$ of incubation at $23^{\circ} \mathrm{C}$ (see Fig. 2). Therefore at room temperature a $6 \mathrm{~h}$ incubation period was used in this study instead of the $90 \mathrm{~min}$ incubation period as reported previously (Shiu et al., 1973). Representative experiments that had been carried out with an incubation period of $90 \mathrm{~min}$ at room temperature were subsequently repeated by using the longer incubation period. Essentially identical results were obtained. In experiments where only specific binding of ${ }^{125} \mathrm{I}$-labelled prolactin was required, determinations of binding were carried out in duplicate, and for each determination another set of 
duplicate tubes was set up in the presence of $2 \mu \mathrm{g}$ of unlabelled ovine prolactin ( $25 \mathrm{i} . \mathrm{u} . / \mathrm{mg}) / \mathrm{ml}$ of incubation medium. In the absence of unlabelled prolactin, $10-20 \%$ of the labelled hormone added to the medium was bound, whereas in the presence of unlabelled prolactin, $80 \%$ less binding was observed. The difference between the two represents specific binding of ${ }^{125} \mathrm{I}$-labelled prolactin.

\section{Results}

\section{Specificity of binding of prolactin to receptors}

We have previously shown that human prolactin as well as prolactin obtained from several other species inhibits the binding of ${ }^{125} \mathrm{I}$-labelled human prolactin to crude membrane fractions obtained from the rabbit mammary gland and that the ability of prolactin preparations to inhibit the binding of ${ }^{125} \mathrm{I}$-labelled prolactin is related to the biological potencies of these preparations (Shiu et al., 1973). Fig. 1 shows that the binding of ${ }^{125}$ I-labelled human prolactin to a 'purified' plasma-membrane fraction has the same characteristics as those demonstrated for the crude membrane fraction. It has also been demonstrated (not shown in Figure) that when ${ }^{125}$ I-labelled human growth hormone is used as the tracer, purified prolactin (25-30i.u./mg) can inhibit the binding of ${ }^{125}$ I-labelled human growth hormone to receptors to the same extent as purified human growth hormone. Similarly, ${ }^{125}$ I-labelled ovine prolactin can also be used instead of ${ }^{125}$ I-labelled human prolactin.

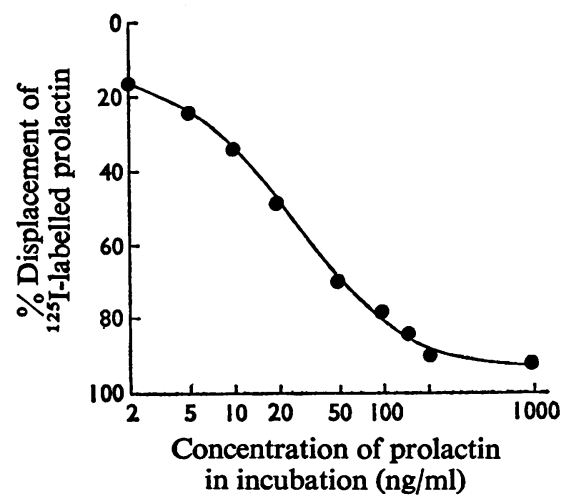

Fig. 1. Binding of ${ }^{125}$ I-labelled human prolactin to 'purified' plasma membranes obtained from the rabbit mammary gland

Plasma membranes were obtained by the method of Neville (1968) as modified by Meldolesi et al. (1971). Procedures for determining binding of ${ }^{125}$ I-labelled prolactin have been described previously (Shiu et al., 1973). The human prolactin used has a potency of 30.5i.u./mg (Frantz et al., 1972a).

Vol. 140
Effects of time and temperature on the binding and dissociation of prolactin

The binding of ${ }^{125} \mathrm{I}$-labelled ovine prolactin is timeand temperature-dependent (Fig. 2). At $37^{\circ} \mathrm{C}$, equilibrium is attained after about $3 \mathrm{~h}$ incubation. However, at $23^{\circ} \mathrm{C}$ (room temperature), specific binding levels off at $5 \mathrm{~h}$. Although the rate of association at $37^{\circ} \mathrm{C}$ is faster than that at $23^{\circ} \mathrm{C}$, the maximal binding that can be achieved at either temperature is similar provided that the incubation period at $23^{\circ} \mathrm{C}$ is prolonged. The binding at $0^{\circ} \mathrm{C}$ is small.

The dissociation of bound ${ }^{125}$ I-labelled ovine prolactin is also time- and temperature-dependent (Fig. 3). Even after $45 \mathrm{~h}$ the amount of bound ${ }^{125} \mathrm{I}$-labelled ovine prolactin that is dissociated at $4^{\circ} \mathrm{C}$ is not greater than $10 \%$. At $23^{\circ} \mathrm{C}$ it takes $45 \mathrm{~h}$ to attain $50 \%$ dissociation. The rate of dissociation is much faster at $37^{\circ} \mathrm{C}$, about $50 \%$ of the bound hormone being dissociated from the receptors within $5 \mathrm{~h}$.

\section{Effect of the iodination procedure on the binding of ${ }^{125}$ I-labelled prolactin to receptors}

Fig. 4 compares the binding of ${ }^{125}$ I-labelled human prolactin preparations obtained by two different iodination procedures. The ${ }^{125}$ I-labelled human prolactin obtained by enzymic iodination is superior because greater specific binding and lower nonspecific binding were observed. When ${ }^{125}$ I-labelled human prolactin iodinated by the method of Hunter \& Greenwood (1962) was tested, much less specific binding was observed and the non-specific binding increased at a rapid rate. Indeed when larger amounts of ${ }^{125}$ I-labelled human prolactin prepared by the method of Hunter \& Greenwood (1962) were used, most of the ${ }^{125}$ I-labelled human prolactin bound to

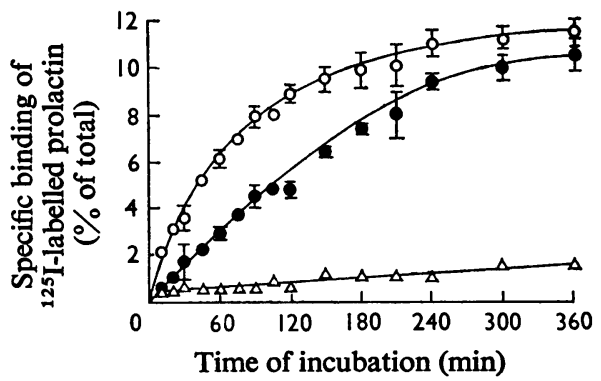

Fig. 2. Effect of time and temperature on the binding of ${ }^{125}$ I-labelled ovine prolactin to membrane fraction

Procedures for determining specific binding are described in the Materials and Methods section. Values are expressed as percentage of total ${ }^{125} \mathrm{I}$-labelled ovine prolactin used in the tube. Vertical bars represent ranges observed in three experiments. $O, 37^{\circ} \mathrm{C} ; \mathrm{O}, 23^{\circ} \mathrm{C} ; \triangle, 0^{\circ} \mathrm{C}$. 


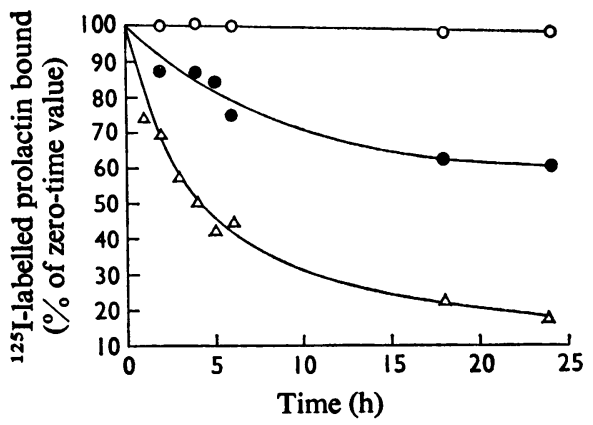

Fig. 3. Effect of time and temperature on dissociation of ${ }^{125}$ I-labelled ovine prolactin from receptors

Membrane fractions were incubated at $23^{\circ} \mathrm{C}$ for $6 \mathrm{~h}$ in the presence or absence of $2 \mu \mathrm{g}$ of ovine prolactin $/ \mathrm{ml}$ and specific binding thus determined was taken as the zerotime value. Another series of tubes that had been incubated in the same fashion were divided into three sets at the end of the $6 \mathrm{~h}$ period. Then $0.5 \mathrm{ml}$ of a solution containing $5 \mu \mathrm{g}$ of ovine prolactin was added to each tube. Each set was incubated at the temperature indicated: $0,4^{\circ} \mathrm{C} ; 0,23^{\circ} \mathrm{C}$; $\triangle, 37^{\circ} \mathrm{C}$. Four tubes from each set were taken out at the time-intervals indicated, and specific binding was determined. Two of the four tubes had been incubated in the presence of, and two in the absence of, ovine prolactin during the first $6 \mathrm{~h}$ of incubation. The former two tubes were included in the dissociation experiment to compensate for any increase in non-specific binding, especially after long periods of incubation.

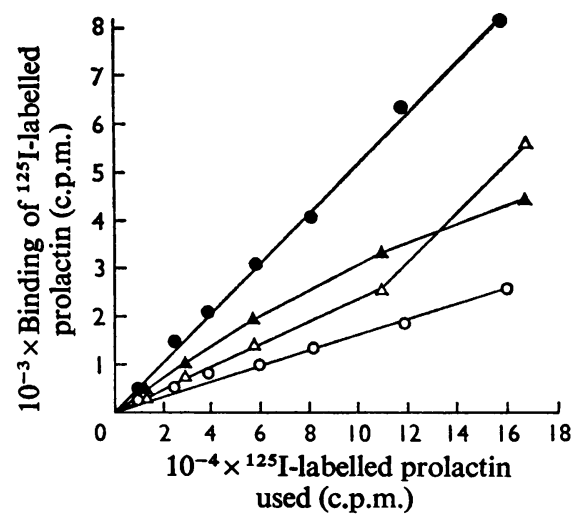

Fig. 4. Effect of iodination procedures on the binding of ${ }_{125}$ I-labelled human prolactin to receptors

Determination of specific and non-specific binding are described in the Materials and Methods section. Specific binding and $O$, non-specific binding for ${ }^{125} \mathrm{I}$ labelled human prolactin iodinated by lactoperoxidase; $\Delta$, specific binding and $\Delta$, non-specific binding for ${ }^{125} \mathrm{I}$ labelled human prolactin prepared by the procedure of Hunter \& Greenwood (1962).

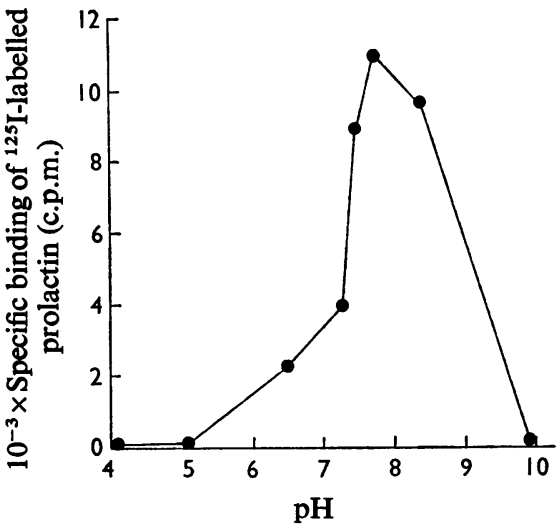

Fig. 5. Effect of pH on specific binding of ${ }^{125}$ I-labelled human prolactin to receptors

Determination of specific binding is described in the Materials and Methods section. Buffers used were: pH4.0-6.5, 0.1 M-sodium acetate-acetic acid; pH7.3, 0.1 M-sodium phosphate; pH7.5-8.4, $0.1 \mathrm{M}$-Tris- $\mathrm{HCl}$; pH 9.9, $0.1 \mathrm{M}-\mathrm{Na}_{2} \mathrm{CO}_{3}-\mathrm{NaHCO}_{3}$. All $\mathrm{pH}$ values are the final $\mathrm{pH}$ in the incubation media. All buffers contained $10 \mathrm{mM}-\mathrm{MgCl}_{2}$ to eliminate the effect of ionic differences in the buffers.

membrane particles was due to non-specific binding. Therefore the ${ }^{125}$ I-labelled prolactin (human or ovine) used in the present study was prepared by the lactoperoxidase method.

\section{Effect of $\mathrm{pH}$ on binding of prolactin to receptors}

The specific binding of ${ }^{125}$ I-labelled human prolactin to receptors occurs over a relatively narrow $\mathrm{pH}$ range. Maximal binding occurs at pH3.7 (Fig. 5), whereas at $\mathrm{pH}$ values less than $6.5^{125} \mathrm{I}$-labelled prolactin precipitates from solution under the incubation conditions used.

Effects of buffers, ionic strength and various salts on binding of prolactin to receptors

The importance of the ionic environment on the binding of prolactin to receptor is shown by the data in Table 1. The greater binding of ${ }^{125} \mathrm{I}$-labelled ovine prolactin in phosphate buffer and Krebs-Ringer bicarbonate buffer (DeLuca \& Cohen, 1964), as compared with Tris- $\mathrm{HCl}$ buffer, probably can be ascribed to the difference in ionic composition rather than to the different buffers. $\mathrm{NaCl}$ at $50 \mathrm{~mm}$ enhances the binding of prolactin. At concentrations from $10 \mathrm{~mm}$ to $25 \mathrm{mM}, \mathrm{CaCl}_{2}$ increases binding threefold. High concentrations of all salts inhibit binding. Combinations of $\mathrm{NaCl}$ and $\mathrm{CaCl}_{2}$ at concentrations that produce maximal stimulation when individual salts are 
Table 1. Effects of buffer and ionic strength on binding of ${ }^{125}$ I-labelled ovine prolactin to receptors

Incubation procedure and determination of specific binding were identical with those described in the Materials and Methods section. The pH of all buffers was adjusted to 7.6.
Buffers used and salts added

Tris- $\mathrm{HCl}(0.025 \mathrm{M})$

Sodium phosphate $(0.05 \mathrm{M})$

Krebs-Ringer bicarbonate

Tris- $\mathrm{HCl}(0.025 \mathrm{M})+0.025 \mathrm{M} \mathrm{NaCl}$

$+0.050 \mathrm{M}-\mathrm{NaCl}$

$+0.250 \mathrm{M}-\mathrm{NaCl}$

$+0.500 \mathrm{M}-\mathrm{NaCl}$

$+1.0 \mathrm{M}-\mathrm{NaCl}$

$+1.5 \mathrm{M}-\mathrm{NaCl}$

$+2.0 \mathrm{M}-\mathrm{NaCl}$

$+0.020 \mathrm{M}-\mathrm{KCl}$

$+0.001 \mathrm{M}-\mathrm{CaCl}_{2}$

$+0.002 \mathrm{M}-\mathrm{CaCl}_{2}$

$+0.005 \mathrm{M}-\mathrm{CaCl}_{2}$

$+0.010 \mathrm{M}-\mathrm{CaCl}_{2}$

$+0.025 \mathrm{M}-\mathrm{CaCl}_{2}$

$+0.050 \mathrm{M}-\mathrm{CaCl}_{2}$

$+0.250 \mathrm{M}-\mathrm{CaCl}_{2}$

$+0.050 \mathrm{M}-\mathrm{NaCl}$

$+0.01 \mathrm{M}-\mathrm{CaCl}_{2}$

$+0.001 \mathrm{M}-\mathrm{MgCl}_{2}$

$+0.010 \mathrm{M}-\mathrm{MgCl}_{2}$
Specific binding of ${ }^{125}$ I-labelled ovine prolactin

(c.p.m.)

5531

9254

13012

7250

8274

7799

6812

6395

4770

3416

7400

7280

9387

10824

14090

14736

12800

3557

13000

8400

14400 used alone do not have an additive effect. Bivalent ions seem to exert a greater effect than univalent ions on promoting the binding of prolactin.

\section{Effect of receptor-protein concentration}

The binding of ${ }^{125}$ I-labelled human prolactin to receptors increases linearly with the amount of receptor protein added (Fig. 6). Normally $200-400 \mu \mathrm{g}$ of membrane protein is used per incubation and under these conditions $10-20 \%$ of ${ }^{125}$ I-labelled prolactin is bound.

\section{Effect of ${ }^{125}$ I-labelled prolactin concentration}

The specific binding of ${ }^{125}$ I-labelled ovine prolactin to receptor particles is a saturable process with respect to prolactin (Fig. 7). Complete saturation, however, is theoretically never reached, as shown in Fig. 7, unless the amount of ${ }^{125} \mathrm{I}$-labelled ovine prolactin used reaches infinity. However, a Lineweaver-Burk (Lineweaver \& Burk, 1934) plot (Fig. 8a) can be constructed from the data shown in Fig. 7. The intercept on the $1 / B$ axis gives $1 / B_{\max }$. Since binding $(B)$ is the amount of prolactin bound, the maximum binding, $B_{\max .}$, is the amount of prolactin bound at saturation.

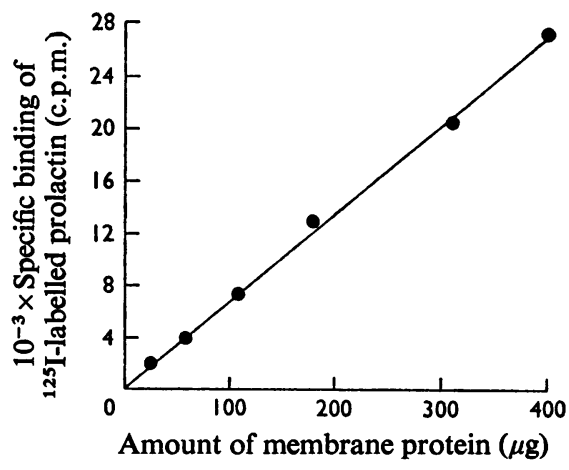

Fig. 6. Effect of amount of membrane proteins on specific binding of ${ }^{125}$ I-labelled human prolactin

Incubation and determination of specific binding of ${ }^{125}$ Ilabelled human prolactin and protein determination are described in the Materials and Methods section.

Thus $B_{\max }$ is the measure of the total number of binding sites, which is $25 \mathrm{fmol} / 450 \mu \mathrm{g}$ of particulate protein or $55.6 \mathrm{fmol} / \mathrm{mg}$ of protein. The intercept on the abscissa gives $-1 / K_{m}$ where $K_{m}$, the concentration of prolactin in the medium at which half-maximal saturation occurs, is $3.4 \times 10^{-10} \mathrm{M}$, or about $8 \mathrm{ng} / \mathrm{ml}$. This is equal to the physiological concentration of prolactin frequently found in serum. The value is near that found in serum of normal subjects and is consistent with the view that small deviations from this value could result in significant metabolic alterations. A Scatchard (1949) plot (Fig. 8b) has also been constructed by using the data of Fig. 7. The intercept on the abscissa gives the maximum amount of prolactin bound, which is $26 \mathrm{fmol} / 450 \mu \mathrm{g}$ of protein $(57.8 \mathrm{fmol} /$ $\mathrm{mg}$ of protein), a value similar to that obtained from the Lineweaver-Burk plot. The reciprocal of the slope yields $K_{\mathrm{d}}$, the dissociation constant, which is $3.4 \times 10^{-10} \mathrm{M}$, identical with the $K_{m}$ value obtained by the Lineweaver-Burk plot. The association constant, $K_{\mathrm{a}}$, is therefore $2.94 \times 10^{9} \mathrm{M}^{-1}$.

\section{Other kinetic studies}

The binding data of Fig. 2 can be used to calculate the rate constant of the prolactin-receptor association, $k_{+1}$, for a reaction of this type:

$$
\text { [Hormone] }+ \text { [receptor] } \underset{k_{-1}}{\stackrel{k_{+1}}{\rightleftharpoons}}
$$

[hormone-receptor complex]

However, we find that our data do not fit the irreversible second-order reaction equation (Maron \& Prutton, 1965) as they appeared to do in the case of the insulin-receptor interaction (Cuatrecasas, 1971a). On the other hand, on substituting the experimental points along the curves in Fig. 2 into the equation for 


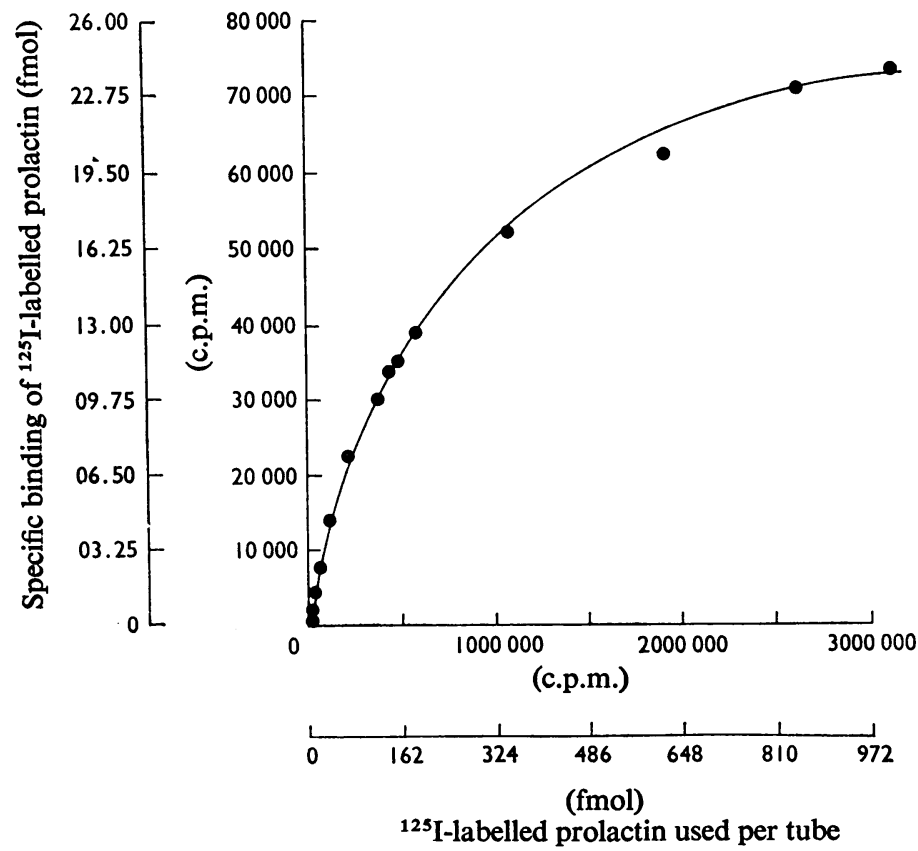

Fig. 7. Effect of amount of ${ }^{125}$ I-labelled ovine prolactin used on specific binding of the labelled hormone

Incubation conditions and procedures for the determination of specific binding were identical with those described in the Materials and Methods section. Molecular weight of ovine prolactin is taken to be 23000 .
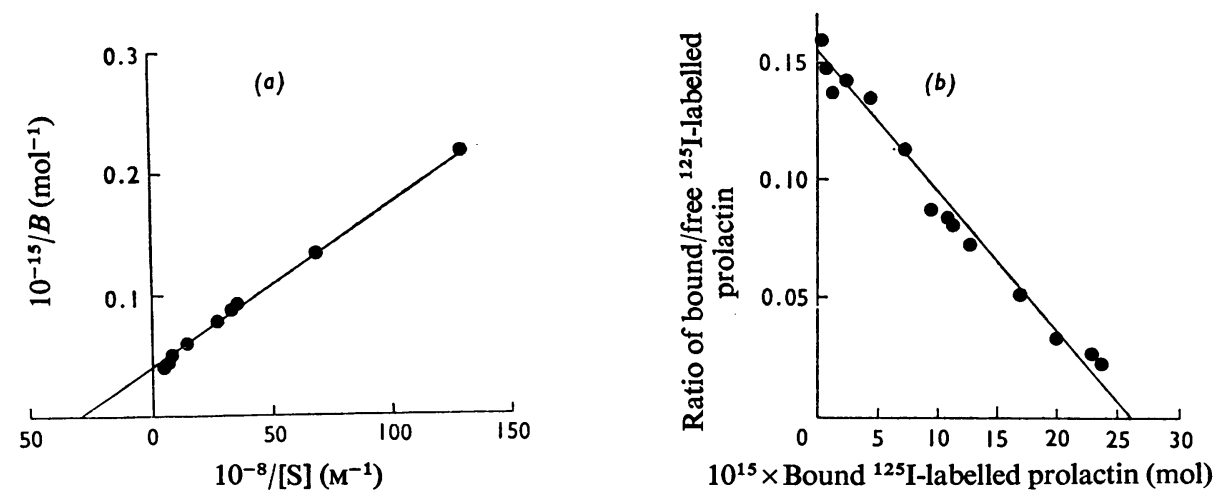

Fig. 8. Kinetic study of prolactin-receptor interaction

(a) Lineweaver-Burk plot of data obtained from Fig. 7 by using the formula:

$$
1 / B=K_{m} / B_{\max .} \cdot 1 /[\mathrm{S}]+1 / B_{\max }
$$

where $B=$ amount of ${ }^{125}$ I-labelled ovine prolactin specifically bound, in fmol; $B_{\max .}=$ maximum binding of ${ }^{125}$ I-labelled ovine prolactin, in fmol; $[\mathrm{S}]=$ concentration of ${ }^{125} \mathrm{I}$-labelled ovine prolactin, in $10^{-8} \mathrm{M}$, used in incubation; and $K_{m}=$ Michaelis constant, or the substrate ( ${ }^{125}$ I-labelled ovine prolactin) concentration at which the binding of ${ }^{125}$ I-labelled ovine prolactin is half-maximal. Intercept on the abscissa gives $-1 / K_{m}$ and intercept on the ordinate gives $1 / B_{\max .0}$ (b) Scatchard plot of data obtained from Fig. 7 by using the formula:

$$
B / F=K-B / K_{\mathrm{d}}
$$

where $B={ }^{125}$ I-labelled ovine prolactin specifically bound, in fmol; $F=$ free ${ }^{125}$ I-labelled ovine prolactin, in fmol; $K_{\mathrm{d}}=$ dissociation constant; and $K=$ constant. Slope of the plot yields $-1 / K_{\mathrm{d}}$ and the intercept on the abscissa yields the total ${ }^{125} I-$ labelled ovine prolactin binding capacity, in fmol, for the amount of membrane protein used $(450 \mu \mathrm{g})$. 
a reversible second-order reaction (Fig. 9) (Maron \& Prutton, 1965) constant values of $k_{+1}$ and linear plots are obtained at both temperatures studied. The average $k_{+1}$ value at $37^{\circ} \mathrm{C}\left(5.6 \times 10^{10} \mathrm{~mol}^{-1} \cdot \mathrm{min}^{-1}\right)$ is more than twice that at $23^{\circ} \mathrm{C}\left(2.6 \times 10^{10} \mathrm{~mol}^{-1}\right.$. $\left.\min ^{-1}\right)$.

\section{Properties of prolactin previously exposed and bound to receptor}

Data presented in Table 2 show that the ${ }^{125} \mathrm{I}$ labelled ovine prolactin recovered from the incubation medium after a $6 \mathrm{~h}$ incubation at $23^{\circ} \mathrm{C}$ and the ${ }^{125}$ I-labelled ovine prolactin eluted from receptor particles are indistinguishable from fresh ${ }^{125} I-$ labelled ovine prolactin in terms of the parameters tested. These results demonstrate that incubation of the hormone with membrane particles and the formation of hormone-receptor complex do not result in a major alteration or destruction of the hormone.

\section{Effect of enzyme treatments on membrane receptor activity}

Brief exposure of receptor particles to trypsin $(50 \mu \mathrm{g} / \mathrm{ml})$ resulted in a $60 \%$ decrease of the binding of ${ }^{125}$ I-labelled ovine prolactin (Table 3 ), suggesting that protein is a functionally important part of the binding site. Phospholipase $\mathrm{C}(50 \mu \mathrm{g} / \mathrm{ml})$ also leads to significant destruction of receptor activity, suggesting that phospholipids may also play a significant role in the binding of prolactin. The absence of any effect of ribonuclease, deoxyribonuclease and neuraminidase on receptor activity suggests that nucleic acids and sialic acid are not essential for the binding of prolactin to its receptor.

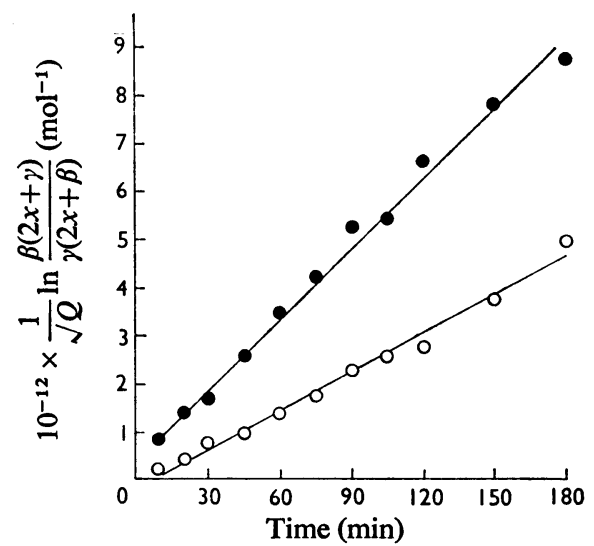

Fig. 9. Determination of rate constant for the association of prolactin and receptor

Association rate constant $\left(k_{+1}\right)$ for the reaction of

$$
\text { [Prolactin] }+ \text { [receptor] } \underset{k_{-1}}{\stackrel{k_{+1}}{\rightleftharpoons}} \text { [prolactin-receptor] }
$$

is calculated utilizing data obtained from Fig. 2. The reversible second-order reaction equation employed for this analysis is:

$$
k_{+1} \cdot t=1 / \sqrt{Q} \cdot \ln [\beta(2 x+\gamma) / \gamma(2 x+\beta)]
$$

(Maron \& Prutton, 1965)

where $Q=D^{2}-4 a b ; \beta=D+\sqrt{ } Q ; \gamma=D-\sqrt{ } Q ; \quad D=$ $(-a-b-c) ; \quad a=$ initial concentration of ${ }^{125}$ I-labelled prolactin ( $32.5 \mathrm{fmol} /$ tube); $b=$ initial concentration of receptor, taken to be $25.5 \mathrm{fmol} / 450 \mu \mathrm{g}$ of membrane proteins (from Scatchard and Lineweaver-Burk plots); $c=\left(a-x_{\mathrm{e}}\right)\left(b-x_{\mathrm{e}}\right) / x_{\mathrm{e}} ; x_{\mathrm{e}}={ }^{125} \mathrm{I}$-labelled prolactin bound at equilibrium, which is $3.44 \mathrm{fmol}$ at $23^{\circ} \mathrm{C}$ and $3.73 \mathrm{fmol}$ at $37^{\circ} \mathrm{C}$ (from Fig. 2); $t=$ time in min; $x={ }^{125}$ I-labelled prolactin bound (fmol) at time $t$. The slope of the straight line yields $k_{+1} \cdot \bullet, 37^{\circ} \mathrm{C}$; $\circ, 23^{\circ} \mathrm{C}$.

Table 2. Comparison of ${ }^{125}$ I-labelled ovine prolactin before and after incubation with membrane fractions

Crude membrane protein $(90 \mathrm{mg})$ was incubated with $80 \times 10^{6} \mathrm{c}$.p.m. of ${ }^{125} \mathrm{I}$-labelled ovine prolactin under conditions identical with those for determination of specific binding. After $6 \mathrm{~h}$ incubation at $23^{\circ} \mathrm{C}$, the membrane particles were centrifuged at $30000 \mathrm{~g}$ for $20 \mathrm{~min}$ at $4^{\circ} \mathrm{C}$. The supernatant was filtered through a Millipore filter (type EGWP, pore size $0.2 \mu \mathrm{m}$ ). The filtrate containing the ${ }^{125}$ I-labelled ovine prolactin that had been exposed to the membrane fraction was subjected to the tests listed in the Table. The pellet was washed with three successive washings of ice-cold buffer (containing $0.1 \%$ bovine serum albumin); each step was followed by centrifugation. The pellet obtained after the final washing was resuspended in $3 \mathrm{ml}$ of $0.01 \mathrm{M}-\mathrm{NaOH}, \mathrm{pH} 12.5$, containing $0.5 \%$ bovine serum albumin. We observed that ${ }^{125} \mathrm{I}$-labelled ovine prolactin precipitates from solution at acid pH under the incubation conditions used; therefore acid cannot be used for dissociation. Exposure to the alkali was brief (about $2 \mathrm{~min}$ ) and the suspension was centrifuged at $30000 \mathrm{~g}$ for $10 \mathrm{~min}$ at $4^{\circ} \mathrm{C}$. The $\mathrm{pH}$ of the supernatant was quickly adjusted to 7.6 with dilute $\mathrm{HCl}$. The neutralized material was filtered through a Millipore filter (same type as above) and the filtrate, containing the ${ }^{125}$ I-labelled ovine prolactin eluted from the membrane particles, was tested. The amount of ${ }^{125}$ I-labelled ovine prolactin that could be eluted by these conditions was about $45 \%$. Determination of specific binding is described in the Materials and Methods section.

${ }^{125} \mathrm{I}$-labelled ovine prolactin

\section{Test}

Percentage adsorbed to talc

Percentage precipitated by $8 \%$ trichloroacetic acid

Percentage bound to excess of rabbit anti-(sheep prolactin) serum

Percentage specifically bound to fresh membranes

$\begin{array}{ccc}\begin{array}{c}\text { Not used } \\ \text { previously }\end{array} & \begin{array}{c}\text { Eluted from } \\ \text { membranes }\end{array} & \begin{array}{c}\text { Recovered from } \\ \text { incubation medium }\end{array} \\ 92 & 80 & 81 \\ 89 & 94 & 87 \\ 73 & 70 & 73 \\ 8.6 & 8.0 & 8.2\end{array}$




\section{Effects of low-molecular-weight compounds}

Various low-molecular-weight compounds that are frequently found in physiological fluids were incubated with the prolactin-binding fractions and specific binding of ${ }^{125} \mathrm{I}$-labelled ovine prolactin was determined. Compounds tested at concentrations of $0.01,0.1,1.0$ and $10 \mu \mathrm{g} / \mathrm{ml}$ (concentrations range from physiological to pharmacological) include: steroid hormones, namely, oestrone, $17 \beta$-oestradiol, oestriol, testosterone, progesterone and cortisol; nucleotides, including dibutyryl cyclic AMP (6- $N-2^{\prime}$-O-dibutyryladenosine $3^{\prime}: 5^{\prime}$-cyclic monophosphate), cyclic AMP, cyclic GMP and the mono-, di- and tri-phosphates of adenosine, cytidine, guanosine and uridine; and other compounds such as GSH, creatine phosphate, the releasing hormone, thyrotrophin-releasing hormone, which is capable of stimulating prolactin release from the pituitary in man (Bowers et al., 1971), and the drug, 2-bromo- $\alpha$-ergocryptine (CB-154), which has been shown to inhibit prolactin secretion in vitro (Pasteels et al., 1971) and in vivo (del Pozo et al., 1972). All these compounds have no effect on the binding of prolactin to receptors.

\section{Distribution of prolactin receptor activity in subcellular fractions obtained from mammary-gland homogenate}

Subcellular fractions obtained by centrifugation of the mammary-gland homogenate prepared as described above were tested for specific binding of ${ }^{125}$ I-labelled prolactin. The highest binding per $\mathrm{mg}$ of protein was observed for the 'purified' plasma-membrane material (Table 4). The crude postmitochondrial material ( $100000 \mathrm{~g}$ pellet) also contains substantial binding capacity ( $76 \%$ of total). The binding activity observed in this fraction is probably due to the presence of appreciableamounts of fragmented plasma membranes, because the 5 '-nucleotidase activity of this fraction is 0.0055 unit $/ \mathrm{mg}$, compared with $0.0039 \mathrm{unit} / \mathrm{mg}$ for the original tissue homogenate.
Further, on refractionation of the total microsomal material by centrifugation on a discontinuous sucrose gradient between $0.3 \mathrm{M}$ - and $1.58 \mathrm{M}$-sucrose, the material recovered at the interphase, which has a $5^{\prime}$ nucleotidase activity of $0.0073 \mathrm{unit} / \mathrm{mg}$, also contains prolactin-binding activity. These observations suggest that fragments of plasma membranes in the original microsomal pellet are responsible for the binding of prolactin, and not the ribosomes or other contaminating subcellular particles found in the same fraction.

Table 3. Effect of enzyme treatment on binding of ${ }^{125} \mathrm{I}$ labelled ovine prolactin by membrane receptors

Portions of membrane suspension were incubated at $37^{\circ} \mathrm{C}$ in the presence of different concentrations of enzyme for $30 \mathrm{~min}$ in the same buffer as was used for binding studies. At the end of the incubation period the content of the tube was centrifuged for $20 \mathrm{~min}$ at $30000 \mathrm{~g}$ at $4^{\circ} \mathrm{C}$. For trypsin digestion, $200 \mu \mathrm{g}$ of soya-bean trypsin inhibitor was added before centrifugation. The pellet was washed three times with cold buffer before resuspension in the incubation buffer. Determination of specific binding of ${ }^{125} \mathrm{I}$ labelled ovine prolactin was identical with that described in the Materials and Methods section.

$\begin{array}{lcc} & \begin{array}{c}\text { Specific binding } \\ \text { Enzyme }\end{array} & \begin{array}{c}\text { Concentration } \\ (\mu \mathrm{g} / \mathrm{ml})\end{array} \\ \begin{array}{l}\text { of I-labelled } \\ \text { ovine prolactin } \\ (\% \text { of control })\end{array} \\ \text { Control } & - & 100 \\ \text { Trypsin } & 50 & 43 \\ \text { Neuraminidase } & 5 & 98 \\ \text { Phospholipase C } & 50 & 103 \\ & 5 & 108 \\ \text { Deoxyribonuclease I } & 50 & 66 \\ & 5 & 96 \\ \text { Ribonuclease } & 50 & 101 \\ & 5 & 96 \\ & 50 & 96\end{array}$

Table 4. Distribution of ${ }^{125}$ I-labelled ovine prolactin-binding activities in subcellular particles isolated from homogenate of rabbit mammary gland

Homogenization conditions and procedures for isolating subcellular particles and the determination of protein and specific binding of ${ }^{125} \mathrm{I}$-labelled ovine prolactin are described in the Materials and Methods section. Nuclear pellet refers to the material recovered in the bottom of the tube after sucrose-gradient centrifugation of the $1500 \mathrm{~g}$ material.

\begin{tabular}{|c|c|c|c|c|c|}
\hline \multirow[b]{2}{*}{ Subcellular particles } & \multirow{2}{*}{$\begin{array}{c}\text { Amount of } \\
\text { particulate } \\
\text { protein added } \\
(\mu \mathrm{g})\end{array}$} & \multicolumn{2}{|c|}{$\begin{array}{l}\text { Specific binding of }{ }^{125} \mathrm{I} \text {-labelled } \\
\text { ovine prolactin }\end{array}$} & \multirow{2}{*}{$\begin{array}{l}\text { Yield of particles } \\
\text { (mg of protein/ } \\
10 \mathrm{~g} \text { of tissue) }\end{array}$} & \multirow{2}{*}{$\begin{array}{l}\text { Percentage of } \\
\text { total binding } \\
\text { activity }\end{array}$} \\
\hline & & (c.p.m.) & (c.p.m./mg of protein) & & \\
\hline Purified membrane & 100 & 3135 & 31350 & 1 & 3 \\
\hline $\begin{array}{l}100000 \mathrm{~g} \text { pellet (postmito- } \\
\text { chondrial material) }\end{array}$ & 400 & 9180 & 22950 & 40 & 76 \\
\hline Nuclear pellet & 170 & 1571 & 9240 & 27 & 21 \\
\hline $\begin{array}{l}15000 \mathrm{~g} \text { pellet (mitochondrial } \\
\text { fraction) }\end{array}$ & 360 & 0 & 0 & - & - \\
\hline
\end{tabular}


Table 5. Prolactin-binding activity in membrane fractions isolated from various organs of the pregnant rabbits

The crude membrane fraction was used throughout. Incubation conditions and determination of specific binding of ${ }^{125} \mathrm{I}$-labelled ovine prolactin were identical for all tissues; $100-300 \mu \mathrm{g}$ of membrane protein was used for each determination. Values represent means \pm S.D. for three rabbits except for the mammary gland, where the value represents mean \pm S.D. for ten rabbits.

Specific binding of ${ }^{125} \mathrm{I}$-labelled ovine prolactin/mg of protein

\begin{tabular}{lr}
\multicolumn{1}{c}{ Organ } & $\left(\%\right.$ of ${ }^{125}$ I-labelled p \\
Adrenal & $51 \pm 4$ \\
Mammary & $25 \pm 5$ \\
Ovary & $13 \pm 1$ \\
Liver & $8 \pm 1$ \\
Kidney & $7 \pm 1$ \\
Heart & $<2$ \\
Lung & $<2$ \\
Brain & $<2$ \\
Muscle (skeletal) & $<2$ \\
Pancreas & $<2$ \\
Spleen & $<2$ \\
Placenta (foetal) & $<2$
\end{tabular}

The binding activity in the 'nuclear' pellet is probably due to intact epithelial cells, as the latter were observed by light-microscopy. The mitochondrial pellet $(15000 \mathrm{~g})$ contains essentially no binding activity.

\section{Prolactin-binding activity in other organs of the preg- nant rabbit}

In view of the diverse actions of prolactin (Nicoll \& Bern, 1972), we have examined the binding of ${ }^{125} \mathrm{I}$ labelled ovine prolactin to crude membrane fractions obtained from a number of organs. Table 5 shows that the adrenal, surprisingly, has the highest prolactin binding per $\mathrm{mg}$ of membrane protein. The ovary, liver and kidney also contain appreciable amounts of prolactin-binding activity. Other tissues tested do not exhibit significant binding of prolactin.

\section{Discussion}

Several recent studies have measured the binding of polypeptide hormones, such as adrenocorticotrophic hormone (Lefkowitz et al., 1970), glucagon (Rodbell et al., 1971), insulin (Cuatrecasas, 1971 $a, b$; Freychet et al., 1971), gonadotrophins (Catt et al., 1972; Kammerman et al., 1972; Lee et al., 1973), growth hormone (Lesniak et al., 1973; Tsushima \& Friesen, 1973), thyroid-stimulating hormone (Amir et al., 1973), calcitonin (Marx et al., 1972) and oxytocin (Soloff et al., 1972), to various membrane fractions of tissue homogenates and intact cells. All these studies suggest that the binding of hormones to a biologically significant site on plasma membranes is perhaps the first step in hormone action. The membrane structure which bind hormone are operationally termed 'receptors'.

The direct action of prolactin on mammary gland has been well documented (Cowie \& Tindal, 1971). The present study demonstrates that receptors capable of binding prolactin are present in plasma-membrane-containing fractions isolated from the rabbit mammary gland. It would be very helpful to be able to correlate the binding of prolactin with other important biochemical actions of prolactin. In view of the important role of cyclic AMP in hormone action, the identification of an interaction between prolactin receptor and the adenylate cyclase system may substantiate the role of receptors in the action of prolactin.

Despite the lack of evidence for biochemical changes in plasma membranes secondary to the binding of prolactin, we believe that the binding of prolactin is specific. We have previously demonstrated that two hormones other than prolactin, namely human growth hormone and human placental lactogen, which are equipotent with prolactin in the rabbit in studies in vivo and in vitro, are the only hormones that are capable of competing with ${ }^{125}$ I-labelled prolactin for the receptor site (Shiu et al., 1973). On the other hand, growth hormones from other species, which cannot compete for the prolactin receptors in our membrane fractions, are also not lactogenic in the rabbit (Cowie \& Tindal, 1971; Forsyth et al., 1965; Forsyth \& Folley, 1970; Forsyth, 1972; Frantz et al., 1972a,b; Barnawell, 1965; Jones \& Cowie, 1972). The finding that ${ }^{125}$ I-labelled ovine prolactin is accumulated by the rabbit mammary gland in vivo (Birkinshaw \& Falconer, 1972) further suggests that the binding of prolactin to membranes in vitro is not an artifact. These results strongly support the notion that binding of prolactin to membrane receptor is a significant physiological event in the action of prolactin.

Similar to the binding of many other hormones to their receptors, the binding of ${ }^{125} \mathrm{I}$-labelled prolactin to its receptor is a reversible process that is time- and temperature-dependent (Figs. 2 and 9). The slow rate of binding of prolactin suggests that the association between the hormone and the receptor is a diffusioncontrolled process, particularly in view of the extraordinary size of the diffusing species. The slow dissociation rate of prolactin from its receptor observed in this study is consistent with the study in vivo by Birkinshaw \& Falconer (1972), which demonstrated that ${ }^{125} \mathrm{I}$-labelled prolactin disappeared from the rabbit mammary gland with an average half-life of $52 \mathrm{~h}$.

The better binding of ${ }^{125} \mathrm{I}$-labelled prolactin prepared by the enzymic iodination to receptors, as compared with that obtained by the Hunter \& Greenwood 
(1962) procedure (Fig. 4), further supports the notion that only biologically active hormones bind to receptors. Our data are consistent with those of Frantz \& Turkington (1972), who showed that ${ }^{125}$ I-labelled prolactin obtained by the enzymic iodination procedure binds much better to membrane receptors isolated from mouse mammary glands and that this preparation of labelled hormone has retained $60 \%$ of its biological activity as compared with $0.7 \%$ for the labelled hormone prepared by the chloramine-T procedure.

Prolactin-receptor formation is not immediately followed by degradation of the labelled hormone (Table 2), suggesting that the binding observed is not the result of binding to proteolytic enzymes that inactivate the hormone. The relative ease with which bound prolactin can be eluted from its receptor also suggests that binding does not involve formation of covalent bonds. The ${ }^{125}$ I-labelled prolactin, which was eluted from the membrane receptors and which was again used for binding studies, proved to bind as well in the second test as in the first, providing further evidence for the integrity of the iodinated hormone and for the lack of any major degradation of hormones after binding had occurred.

Destruction of receptor activity by treatments with trypsin and phospholipase $C$ (Table 3) indicates that protein and phospholipid constituents are structural components that are essential for receptor activity. The lack of any effect on prolactin binding by steroid hormones, nucleotides and other low-molecularweight compounds suggest that these substances do not play any significant role in the formation of the hormone-receptor complex.

As in other studies on the binding of polypeptide hormones, subcellular fractions that contain prolactin-binding activity also possess 5 '-nucleotidase activity. Since Keenan et al. $(1970,1972)$ have demonstrated that 5'-nucleotidase is a valid marker enzyme for plasma membrane of the mammary gland, the abundance of 5 -nucleotidase activity in the postmitochondrial particles indicates that this fraction contains fragmented plasma membranes, presumably as a result of the homogenization conditions used for this relatively tough tissue. It is therefore reasonable to assume that the prolactin receptors that we observe are located on cell surface membranes.

The presence of specific prolactin-binding sites in membrane fractions isolated from organs other than the mammary gland is not surprising in view of the many diverse actions of prolactin. Indeed, Nicoll \& Bern (1972) have listed over 80 actions of prolactin in a large number of organs and tissues in many species. It is not known whether the high degree of binding of prolactin by the adrenal is due to the presence of more receptors, or whether the adrenal receptors have a higher affinity for prolactin. Alternatively, the homogenizing procedure that was used may have resulted in a better yield of plasma membranes from the adrenal gland than from other tissues. The stimulation of thymidine kinase and thymidylate kinase activities in rat adrenocarcinomas by injections of prolactin (Thomson et al., 1973) and the ability of prolactin to restore corticosterone biosynthesis in adrenals from hypophysectomized rats (Lis et al., 1973) certainly suggest that the adrenal is a possible target for prolactin, and the potential significance of prolactin receptors in this organ becomes quite obvious. The luteotrophic role of prolactin and the effects of prolactin on kidney function (Nicoll \& Bern, 1972) suggest that the binding of prolactin to the ovary and kidney may be physiologically significant.

The present studies indicate that membrane fractions derived from the rabbit mammary gland possess biologically significant receptors for prolactin. They provide yet another example of polypeptide-hormone interaction with its target tissue. They also set forth procedures that will prove useful for the further characterization and isolation of prolactin receptors.

We appreciate the secretarial help of Mrs. Jennie Cardinal, the preparation of figures by Mrs. Jean Parodo and the skilful technical assistance of Miss Teresa Cody. The work was supported by the Medical Research Council of Canada (grant MA-2525), the U.S. Public Health Service Child Health and Human Development (grant HD-01727-08) and the National Cancer Institute (contract E-C-72-26).

\section{References}

Amir, S. M., Carraway, T. F., Kohn, L. D. \& Winand, R. J. (1973) J. Biol. Chem. 248, 4092-4100

Barnawell, E. B. (1965) J. Exp. Zool. 160, 189-206

Birkinshaw, M. \& Falconer, I. R. (1972) J. Endocrinol. 55, 323-334

Bowers, C. Y., Friesen, H., Hawang, P., Guyda, H. \& Folkers, K. (1971) Biochem. Biophys. Res. Commun. 45, 1033-1041

Catt, K. J., Dufau, M. L. \& Tsuruhara, T. (1972) J. Clin. Endocrinol. Metab. 34, 123-132

Cowie, A. T. \& Tindal, J. S. (1971) Physiology of Lactation, Edward Arnold (Publishers) Ltd., London

Cuatrecasas, P. (1971a) Proc. Nat. Acad. Sci. U.S. 68, 1264-1268

Cuatrecasas, P. (1971b) J. Biol. Chem. 246, 7265-7274

del Pozo, E., Brun del Re, R., Varga, L. \& Friesen, H. (1972) J. Clin. Endocrinol. Metab. 35, 768-771

DeLuca H. F. \& Cohen, P. P, (1964) in Manometric Techniques (Umbreit, W. W., Burris, R. H. \& Schneider, W. C., eds.), 4th edn., pp, 131-133, Burgess Publishing Co. Minneapolis

El-Aaser, A. A. \& Reid, E. (1965) Abstr. FEBS Meet. 2nd, Vienna 41

Falconer, I. R. (1972) Biochem. J. 126, 8 P-9P

Forsyth, I. A. (1972) in Ciba Foundation Symposium on Lactogenic Hormones (Wolstenholme, G. E. W. \& Knight, J., eds.), pp. 151-167, Churchill, London 
Forsyth, I. A. \& Folley, S. J. (1970) in Ovo-Implantation, Human Gonadotrophins and Prolactin (Hubinont, P. O., Leroy, F., Robyn, C. \& Leleux, P., eds.), pp. 266-278, Karger, Basel and New York

Forsyth, I. A., Folley, S. J. \& Chadwick, A. (1965) J. Endocrinol. 31, 115-126

Frantz, A. G., Kleinberg, D. L. \& Noel, G. L. (1972a) Recent Progr. Horm. Res. 28, 527-573

Frantz, A. G., Kleinberg, D. L. \& Noel, G. L. (1972b) in Ciba Foundation Symposium on Lactogenic Hormones (Wolstenholme, G. E. W. \& Knight, J., eds.), pp. 137150, Churchill, London

Frantz, W. L. \& Turkington, R. W. (1972) Endocrinology 91, 1545-1548

Freychet, P., Roth, J. \& Neville, D. M. (1971) Proc. Nat. Acad. Sci. U.S. 68, 1833-1837

Friesen, H. G. (1966) Endocrinology 79, 212-215

Hunter, W. M. \& Greenwood, F. C. (1962) Nature (London) 194, 495-496

Hwang, P., Guyda, H. \& Friesen, H. (1972) J. Biol. Chem. 247, 1955-1958

Jones, E. A. \& Cowie, A. T. (1972) Biochem. J. 130, 9971002

Kammerman, S., Canfield, R. E., Kolena, J. \& Channing, C. P. (1972) Endocrinology 91, 65-74

Keenan, T. W., Morré, J., Olson, D. E., Yunghams, W. N. \& Patton, S. (1970) J. Cell Biol. 44, 80-93

Keenan, T. W., Huang, C. M. \& Morré, J. (1972) Biochem. Biophys. Res. Commun. 47, 1277-1283

Lee, C. Y., Caulam, C. B., Jiang, N. S. \& Ryan, R. J. (1973) J. Clin. Endocrinol. Metab. 36, 148-152

Lefkowitz, R. J., Roth, J., Pricer, W. \& Pastan, I. (1970) Proc. Nat. Acad. Sci. U.S. 65, 745-752

Lesniak, M. A., Roth, J., Gorden, P. \& Gavin, J. R. (1973) Nature (London) New Biol. 241, 20-22
Lineweaver, H. \& Burk, D. (1934) J. Amer. Chem. Soc. 56, 658-666

Lis, M., Gilardeau, C. \& Chretien, M. (1973) Clin. Res. 21, 1027

Maron, S. H. \& Prutton, C. F. (1965) Principles of Physical Chemistry, 4th edn., pp. 548-597, MacMillan Co., New York

Marx, S. J., Woodard, C. J. \& Aurbach, G. D. (1972) Science 178, 999-1000

Meldolesi, J., Jamieson, J. D. \& Palade, G. E. (1971) J. Cell Biol. 49, 109-129

Neville, D. M. (1968) Biochim. Biophys. Acta 154, 540-552

Nicoll, C. A. \& Bern, H. A. (1972) in Ciba Foundation Symposium on Lactogenic Hormones (Wolstenholme, G. E. W. \& Knight, J., eds.), pp. 299-317, Churchill, London

Pasteels, J. L., Danguy, A., Frerotte, M. \& Ectors, F. (1971) Ann. Endocrinol. 32, 188-192

Rodbell, M., Kraus, H. M. J., Pohl, S. L. \& Birnbaumer, L. (1971) J. Biol. Chem. 246, 1861-1871

Scatchard, G. (1949) Ann. N.Y. Acad. Sci. 51, 660-672

Shiu, R. P. C., Kelly, P. A. \& Friesen, H. G. (1973) Science 180, 968-971

Soloff, M. S., Swartz, T. L. \& Saffran, M. (1972) Endocrinology, 91, 231-216

Thomson, M. J., Garland, M. R. \& Richards, J. F. (1973) Cancer Res. 33, 220-225

Thorell, J. I. \& Johansson, B. G. (1971) Biochim. Biophys. Acta 251, 363-369

Tsushima, T. \& Friesen, H. G. (1973) J. Clin. Endocrinol. Metab. 37, 334-337

Turkington, R. W. (1970) Biochem. Biophys. Res. Commun. 41, 1362-1367

Turkington, R. W. (1971) J. Clin. Invest. 50, 94

Widnell, C. C. \& Unkeless, J. C. (1968) Proc. Nat. Acad. Sci. U.S. 61, 1050-1075 